\title{
Relationship between Parental Marital Status and Students' Academic Performance in Day Secondary Schools of Dagoretti Sub District of Nairobi County,
}

Kenya.

\section{Rosemary Mueni Mutisya ${ }^{1^{*}}$, Edward Kigen ${ }^{1}$, Doyne Mugambi $^{1}$ Boaz Migosi $^{1}$ \\ ${ }^{1}$ Department of Educational Psychology, Kenyatta University, P.O. Box, 43844, 00100, Nairobi, Kenya. boazmigosi@gmail.com}

\section{Abstract}

Academic performance is one of the important aspects of a student's life and therefore it is important to understand the factors that hinder or promote it. Various researches on factors affecting performance have been done, however there is little local research on how family structure affects academic performance. This study examined students' academic performance vis-à-vis single and two parent family structures. It also investigated if there were any gender differences in academic performance as determined by parental marital status. The target population was form three students in day secondary schools of Dagoretti Sub District, Nairobi County, Kenya. The sample of the study consisted of 196 students drawn from five day secondary schools. The study used descriptive survey and ex post facto methodology. Simple random and purposive sampling techniques were used to select the schools and classes for the study respectively. Questionnaires and class achievement records 
were used to collect data. The data was analyzed using Analysis of Variance (ANOVA), t-test and Chi-square test at significance level of 0.05. The study found no relationship between parental marital status and students' academic performance as majority of students, regardless of family structure, performed equally poorly with a mean grade of less than ' $C$ '. The results showed that there was no difference in the academic performance of students from single and two parent families $(P=0.776)$. Additionally, the results indicated that there was no significant difference in the academic performance of male and female students from single and two parent families $(P=0.348)$ and altogether these outcomes established that there was no bearing between parental marital status and students' academic performance $(P=0.873)$. On the basis of this finding, it was recommended that parents and schools/ teachers should provide necessary conduciveness to all learners to deal with the challenges they face at home and school, in order to obtain desired academic performance.

Keywords: Intact family, Non Intact family

\section{Introduction}

Academic performance is one of the most important aspects of a student's life. Secondary education comes between primary and tertiary levels and its programs have had a functional role of giving students access to higher education, preparing students for lifelong education and work (World Bank, 
2002). According to Lewin (2004) access to and success in secondary schooling will continue to be highly correlated with subsequent employment and income distribution patterns.

It is important to understand the factors that promote or hinder students' academic performance in order to effect changes necessary to bring about success. Researches on various factors affecting academic performance have been carried out. Some of the major factors found affecting day secondary schools in developing countries are domestic chores, biased upbringing that portrays boys as superior to girls in all aspects of maturation, poor school environments and insensitive teaching methods that disregard the student's needs (FAWE, 2003b).

Most parents want their children to succeed in school but are often unaware that family life itself has a significant impact on their child's academic capacity (Fagan, Have \& Chen, 2011). Previous research has found a direct link between academic achievement and the family with regard to family size, socioeconomic status, educational environment at home and parental marital status. Conly and Glauber (2005) argued that unplanned families put a strain on the monetary and nonmonetary resources of the guardians thereby hampering school achievement of the children. Orr (2003) found that in America the presence of educational resources was positively correlated with academic achievement. A study by Downey (1995) in America found that the more the children, the more thinly spread the interpersonal time and economic resources 
were from the parents. According to a research by Ajila and Olutola (2007) on the impact of socio-economic status on university students' academic performance in Nigeria, the state of the home affects the individual since the parents are the first socializing agents in an individual's life. This is because the family background and context of a child affect his reaction to life situations and his level of performance.

According to Center for Marriage and Families (CMF, 2005) in America, family structure affects preschool readiness. It affects educational achievement at the elementary, secondary, and college levels. Family structure affects a range of child behaviours that can bear directly on educational success, such as school misbehaviour, drug and alcohol consumption, sexual activity and teen pregnancy, and psychological distress. Other studies show that the level of family cohesion and family relationships (Buote, 2001) prove themselves capable of predicting performance.

Parental marital status has been found to have an impact on academic performance of students. Compared to children who live with both parents until adulthood, children from divorced families were found to have lower educational expectations, poorer school attendance and lower grades in America (Amato 2001, Sun \& Li 2001). They were also less likely to graduate from high school or to attend college (Ploeg 2002, Bilblarz \& Gottainer 2000, Pong et al. 2002). A research in America on 
family structure and child well-being found out that children and adolescents in intact married families were more likely to care about doing well in school, to do schoolwork without being forced, to do more than "just enough to get by," and to do their homework (Brown, 2004).

A research carried out by Uwaifo (2008) on the effect of family structure and parenthood on the academic achievement of Nigerian university students found that a significant difference existed between the academic performance of students from single parent family and students from two-parent family structures. Also there was a significant difference in academic performance of male and female students compared on the two types of family structures (Uwaifo, 2008).

A study by Omenge and Nasongo (2010) on the effects of socialization with regard to gender roles on students' academic achievement in secondary schools in Kenya found that students' participation in domestic chores was linked to low academic achievement. They also found that in both boys and girls, academic achievement was equally affected by engagement in domestic duties. Jagero (2011) found that lack of discipline during study time, lack of adequate reading facilities and inadequate boarding facilities affected academic achievement of boarding secondary schools in Kenya. He also found that parental support and economic status affect academic performance of students. 
Dagoretti Sub District of Nairobi County has many secondary school-going students from both single and two parent families whose good academic performance or lack of it could not be attributed to factors related to either of the two family structures. This study investigated relationships between single/two parent families and academic performance with the purpose of enriching the research pool concerned with their associations.

\section{Objectives of the Study}

a) To assess the relationship between single parent families and the academic performance of their children in day secondary schools

b) To assess the relationship between two parent families and the academic performance of their children in day secondary schools

c) To establish if there was a difference in the academic performance of students from single and two parent families

d) To establish whether there were gender differences in academic performance of students from single and two parent families 


\section{Methodology}

Target Population, Sampling Techniques, Sample Size and Data Collection Technique

The study targeted all form three students attending day secondary schools and their class teachers in Dagoretti Sub District of Nairobi County. Using probability and nonprobability sampling techniques, a total of 196 students from five secondary schools were sampled for the study, $53.1 \%$ of whom were females and $46.9 \%$ males. Data on the independent variables (parental marital status) was gathered by use of questionnaires whereas data on the dependent variable (students' academic performance) was obtained from the students' achievement records. 


\section{Data Analysis}

Descriptive and inferential analysis was done according to the study objectives and data presented in the most appropriate forms. Demographic data is provided below.

\section{Table 3.1.Demographic information of respondents}

\begin{tabular}{lll}
\hline Age & Frequency $(\mathbf{n = 1 9 2})$ & $\mathbf{\%}$ \\
\hline $15-17$ & 141 & 72.0 \\
$18-20$ & 53 & 27.0 \\
Above 20 & 1 & 0.5 \\
Missing & 1 & 0.5 \\
Gender & & \\
Male & 92 & 46.9 \\
Female & 104 & 53.1 \\
Type of family of & & \\
& & \\
respondents & 130 & 66.3 \\
Two parent family & 60 & 30.6 \\
Single parent family & 6 & 3.1 \\
Orphan & & \\
Whom they live with & 83 & 42.3 \\
Both biological parents & 16 & 8.2 \\
One biological \& one step & & \\
parent & & 7.1 \\
Father only & 14 & 27.0 \\
Mother only & 53 & 11.7 \\
Relative & 26 & \\
Other* & 4 & \\
\hline
\end{tabular}


Alone (1) Girlfriend (1), Good Samaritan (1), Government/ NGO Shelters (1)

Of the 190 respondents who had living parents, 120 (63.2\%) reported that their parents were currently married while the rest had parents who were divorced (18.4\%), never married $(10.5 \%)$ or widowed (7.9\%) as presented in Figure 3.1.

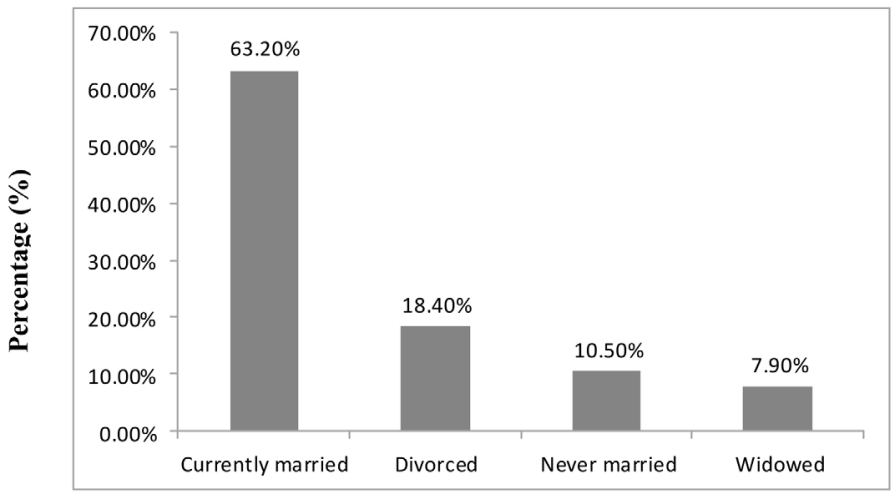

Marital status of parents $(n=190)$

Figure 3.1 Marital Status of the Parents of the respondents 


\section{Results}

\section{Relationship between Single Parent Families and Academic Performance of their Children}

Based on the first study objective, "To assess the relationship between single parent families and the academic performance of their children in day secondary schools" data collected was analyzed to show the academic performance of the respondents. Table 4.1 presents a summary of distribution of the academic performance of the students from single parent families based on the results of Form III, term II, 2012. Most students scored below $\mathrm{C}+$.

Table 4.1: Academic Performance Results of Students from Single Parent Families

\section{Corresponding}

Average Grade

E

D-

$\mathrm{D}$

D+

C-

C

C+

B-

B

B+
Points

$$
1
$$

2

3

4

5

6

7

8

9

10
Frequency $(\mathbf{n}=\mathbf{5 7})$

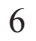

4

2

9

5

7

13

6

3

2
$\%$

10.5

7.0

3.5

15.8

8.8

12.3

22.8

10.5

5.3

3.5 
In the analysis, students who had reportedly scored a mean grade of above $\mathrm{C}+$ were rated as 'good' while their counterparts who had reportedly scored less than a mean grade of a $\mathrm{C}+$ were classified as 'poor'. This rating was based on the minimum entry requirements for Kenyan universities.

To find out if there was any relationship between single parent families and academic performance of their children, the student's response on various questions that were hypothesized to have contributed to the student's academic performance were rated on a five-point Likert scale (Never, rarely, sometimes, many times and always). For analytical purposes, these responses were dichotomized into yes (many times and always) and no (Never, rarely and sometimes). Table 4.2 outlines the relationship between single parent family settings, and academic performance of their children. Students from single parent families were found not to miss school although the relationship between missing school and performance was not significant $\left(\chi^{2}=0.97\right)$. On the other hand, often doing studies at home was associated significantly with improved student's academic performance $\left(\chi^{2}=3.980 \mathrm{df}\right.$ $=1, \mathrm{p}=0.046)$ for single parent families. A significantly higher proportion of students who affirmed that they often did their studies at home were found to have performed better than those who responded to the contrary (35.3\% versus $12.5 \%)$ for single parent families. The participating students were also asked whether they participated in the learning process or 
answered questions in class. There were more students who responded in the affirmative and had their performance rated as good than those who responded in the negative. However, the difference in proportions was not statistically significant (27.6\% versus $\left.10.7 \%, \chi^{2}=2.604, \mathrm{df}=1, \mathrm{p}=0.107\right)$ for students from single parent families. Significant association was found between finishing homework and academic performance on the students from single parent families $\left(\chi^{2}=2.556, \mathrm{df}=1\right.$, $\mathrm{p}=0.110$; Table 4.2).

\section{Table 4.2 Academic Performance of Students from Single Parent Families}

\begin{tabular}{|c|c|c|c|c|c|}
\hline Characteristic & Good & $\begin{array}{l}\text { Performance } \\
\text { Poor }\end{array}$ & $\chi^{2}$ & df & P-value \\
\hline \multicolumn{6}{|c|}{ Do you often miss school in a week? $(n=57)$} \\
\hline Yes & $0(0.0 \%)$ & $0(0.0 \%)$ & 0.001 & 1 & 0.97 \\
\hline No & $11(80.7 \%)$ & $46(80.7 \%)$ & & & \\
\hline Overall & $11(80.7 \%)$ & $46(80.7 \%)$ & & & \\
\hline \multicolumn{6}{|c|}{ Do you often do your studies at home? $(n=57)$} \\
\hline Yes & $6(35.3 \%)$ & $11(64.7 \%)$ & 3.980 & 1 & 0.046 \\
\hline No & $5(12.5 \%)$ & $35(87.5 \%)$ & & & \\
\hline Overall & $11(19.3 \%)$ & $46(80.7 \%)$ & & & \\
\hline \multicolumn{6}{|c|}{ Do you participate/answer questions in class? $(n=57)$} \\
\hline Yes & $8(27.6 \%)$ & $21(72.4 \%)$ & 2.604 & 1 & 0.107 \\
\hline No & $3(10.7 \%)$ & $25(89.3 \%)$ & & & \\
\hline Overall & $11(19.3 \%)$ & $46(80.7 \%)$ & & & \\
\hline \multicolumn{6}{|c|}{ Do you often finish your homework? $(\mathrm{n}=57)$} \\
\hline Yes & $11(22.9 \%)$ & $37(77.1 \%)$ & 2.556 & 1 & 0.110 \\
\hline No & $0(0.0 \%)$ & $9(100.0 \%)$ & & & \\
\hline Overall & $11(19.3 \%)$ & $46(80.7 \%)$ & & & \\
\hline
\end{tabular}

Though the proportion of students whose academic performance was good was higher for those who cared about doing well in school, this difference was not statistically significant as shown in Table 4.3. In addition, whether a student 
often got satisfied with his/her academic performance, or not, was not significantly related with academic performance. Students who viewed school rules as strict tended to perform poorly as opposed to those who were of the opinion that school rules were either moderate or not strict. The academic performance of students, who often discussed their academic performance with someone, was not statistically different from their colleagues who had no one to discuss their performance with. Limiting the amount of time a student spent in pass time activities e.g. watching TV was not related statistically with academic performance as Table 4.3 shows. 
Table 4.3 Academic Performance of Students from Single Parent Families

\section{SingleParent}

\section{Family Student Performance}

\begin{tabular}{|c|c|c|c|c|c|}
\hline Characteristic & Good & Poor & $\chi^{2}$ & df & P-value \\
\hline \multicolumn{6}{|c|}{ Do you care about doing well in school? $(n=57)$} \\
\hline Yes & $11(20.4 \%)$ & $43(79.6 \%)$ & 0.757 & 1 & 0.384 \\
\hline No & $0(0.0 \%)$ & $3(100.0 \%)$ & & & \\
\hline Overall & $11(19.3 \%)$ & $46(80.7 \%)$ & & & \\
\hline \multicolumn{6}{|c|}{ Do you often get satisfied with your performance? $(n=56)$} \\
\hline Yes & $4(33.3 \%)$ & $8(66.7 \%)$ & 1.814 & 1 & 0.178 \\
\hline No & $7(15.9 \%)$ & $37(84.1 \%)$ & & & \\
\hline Overall & $11(19.6 \%)$ & $45(80.4 \%)$ & & & \\
\hline \multicolumn{6}{|c|}{ How do you view your school rules? $(n=57)$} \\
\hline Strict & $2(16.7 \%)$ & $10(83.3 \%)$ & 0.068 & 1 & 0.795 \\
\hline Moderate/Not strict & $9(20.0 \%)$ & $36(80.0 \%)$ & & & \\
\hline Overall & $11(19.3 \%)$ & $46(80.7 \%)$ & & & \\
\hline \multicolumn{6}{|c|}{ Do you discuss your performance with anybody? $(n=57)$} \\
\hline Yes & $10(19.2 \%)$ & $42(80.8 \%)$ & 0.002 & 1 & 0.967 \\
\hline No & $1(20.0 \%)$ & $4(80.0 \%)$ & & & \\
\hline Overall & $11(19.3 \%)$ & $46(80.7 \%)$ & & & \\
\hline \multicolumn{6}{|c|}{ Whom do you discuss your performance with? $(n=52$} \\
\hline Father & $1(16.7 \%)$ & $5(83.3 \%)$ & 0.117 & 2 & 0.943 \\
\hline Mother & $7(20.6 \%)$ & $27(79.4 \%)$ & & & \\
\hline Relatives/Other & $2(16.7 \%)$ & $10(83.3 \%)$ & & & \\
\hline Overall & $10(19.2 \%)$ & $42(80.8 \%)$ & & & \\
\hline
\end{tabular}

Do your parent(s)/guardian(s) limit amount of time you spend on pass time activities e.g watching TV? (n=55)

$\begin{array}{lrrrrr}\text { Yes } & 6(24.0 \%) & 19(76.0 \%) & 0.458 & 1 & 0.498 \\ \text { No } & 5(16.7 \%) & 25(83.3 \%) & & & \\ \text { Overall } & 11(20.0 \%) & 44(20.0 \%) & & & \end{array}$

Single parents who contacted their children's schools to enquire about their academic performance and/or behavior contributed to improved academic performance of the children significantly ( $35.7 \%$ versus $\left.11.9 \%, \mathbb{Q}^{2}=4.058, \mathrm{df}=1, \mathrm{p}=0.044\right)$. Attending school meetings or even taking part in the school activities by the parent was not found to contribute in a significant way to the student's academic performance (Table 4.4). Provision of the student with the parental love/warmth 
did not show any association with student's performance. This was also the case for the student getting advice about general life issues (Table 4.4). Generally, students who reported that they often got assigned domestic duties at home performed poorly than those who reported the opposite regardless of their family background as shown in Table 4.4.

Table 4.4 Single Parent Family and Academic Performance of their Children

\section{Single Parent Family Students performance}

\begin{tabular}{llllll} 
Characteristic & Good & Poor & $\chi^{2}$ & df & P-value \\
\hline \multicolumn{4}{r}{ Parent contact school about student performance/behavior? $(\mathbf{n}=56)$} \\
Yes & $5(35.7 \%)$ & $9(64.3 \%)$ & 4.058 & 1 & 0.044 \\
No & $5(11.9 \%)$ & $37(88.1 \%)$ & & & \\
Overall & $10(17.9 \%)$ & $46(82.1 \%)$ & & &
\end{tabular}

Attend school meetings/take part in the school activities? $(\mathrm{n}=123)$

Yes $\begin{array}{lllll}5(13.9 \%) & 31(86.1 \%) & 1.082 & 1 & 0.298\end{array}$

No $5(25.0 \%) \quad 15(75.0 \%)$

Overall $10(17.9 \%) \quad 46(82.1 \%)$

Provides student with the love/warmth (s)he requires? $(n=123)$ Yes $5(13.2 \%) \quad 33(86.8 \%)$ $1.780 \quad 1$ 0.182

No $5(27.8 \%) \quad 13(72.2 \%)$

Overall

$$
10(17.9 \%) \quad 46(82.1 \%)
$$

Student gets advice from parent about general life issues? $(\mathbf{n}=\mathbf{1 2 3})$

Yes

$$
7(16.3 \%) \quad 36(83.7 \%)
$$

$0.314 \quad 1$

0.575

No

$3(23.1 \%) \quad 10(76.9 \%)$

Overall

$$
\text { 10(17.9\%) } \quad 46(82.1 \%)
$$

Students gets assigned domestic duties/ $\mathbf{n}=\mathbf{1 2 2}$ )

$\begin{array}{llllll}\text { Yes } & 4(12.1 \%) & 29(87.9 \%) & 1.802 & 1 & 0.179 \\ \text { No } & 6(26.1 \%) & 17(73.9 \%) & & & \end{array}$


Relationship between Two Parent Families and Academic Performance of their Children

Based on the second study objective, "To assess the relationship between two parent families and the academic performance of their children in day secondary schools" results indicated that most of the students in two parent families attained a mean grade of below $\mathrm{C}+$ which was rated as poor (Table 4.5)

Table 4.5: Academic Performance Results of Students from Two Parent Families

\begin{tabular}{cccc}
\hline & Corresponding & & \\
Average Grade & Points & Frequency $(\mathrm{n}=123)$ & $\%$ \\
E & 1 & 8 & 6.5 \\
D- & 2 & 8 & 6.5 \\
D & 3 & 8 & 6.5 \\
D+ & 4 & 21 & 17 \\
C- & 5 & 24 & 19.5 \\
C & 6 & 5 & 4.0 \\
C+ & 7 & 23 & 18.7 \\
B- & 8 & 10 & 8.1 \\
B & 9 & 8 & 6.5 \\
B+ & 10 & 6 & 4.9 \\
A- & 11 & 2 & 1.6
\end{tabular}

In two parent families, better performance was observed amongst students who reported that they did not often miss 
school although the relationship between missing school and performance was not significant in both cases. Doing studies at home was associated significantly with improved student's academic performance in two parent families $\left(\chi^{2}=5.013, \mathrm{df}=\right.$ $1, p=0.025)$. A significantly higher proportion of students who affirmed that they often did their studies at home were found to have performed better than those who responded to the contrary (30.8\% versus $14.1 \%)$. The participating students were also asked whether they participated in the learning process or answered questions in class. There were more students who responded in the affirmative and had their performance rated as good than those who responded in the negative and this was statistically significant for students from two parent families (30.8\% against $14.1 \%$ respectively, $\left.\chi^{2}=4.672, \mathrm{df}=1, \mathrm{p}=0.031\right)$. Finishing homework was not significantly associated with academic performance of students from two parent families $\left.\left(\chi^{2}=0.006, \mathrm{df}=1, \mathrm{p}=0.937\right)\right)$ as in Table 4.6. 
Table 4.6 Academic Performance of Students from Two Parent Families

\section{Two Parent Family \\ Student Performance}

\begin{tabular}{|c|c|c|c|c|c|}
\hline \multirow[b]{2}{*}{ Characteristic } & \multicolumn{2}{|c|}{$\begin{array}{l}\text { Two Parent Family } \\
\text { Student Performance }\end{array}$} & \multirow[b]{2}{*}{$\gamma^{2}$} & \multirow[b]{2}{*}{ df } & \multirow[b]{2}{*}{ P-value } \\
\hline & Good & Poor & & & \\
\hline \multicolumn{3}{|c|}{ Do you often miss school in a week? $(n=122)$} & \multirow{4}{*}{0.005} & \multirow{4}{*}{1} & \multirow{4}{*}{0.942} \\
\hline Yes & $1(20.0 \%)$ & $4(80.0 \%)$ & & & \\
\hline No & $25(21.4 \%)$ & $92(78.6 \%)$ & & & \\
\hline Overall & $26(21.3 \%)$ & $96(78.7 \%)$ & & & \\
\hline \multicolumn{3}{|c|}{ Do you often do your studies at home? $(n=123)$} & \multirow{4}{*}{5.013} & \multirow{4}{*}{1} & \multirow{4}{*}{0.025} \\
\hline Yes & $16(30.8 \%)$ & $36(69.2 \%)$ & & & \\
\hline No & $10(14.1 \%)$ & $61(85.9 \%)$ & & & \\
\hline Overall & $26(21.1 \%)$ & $97(78.9 \%)$ & & & \\
\hline \multicolumn{3}{|c|}{ Do you participate/answer questions in class? $(n=120)$} & \multirow{4}{*}{4.672} & \multirow{4}{*}{1} & \multirow{4}{*}{0.031} \\
\hline Yes & $17(30.4 \%)$ & $39(69.6 \%)$ & & & \\
\hline No & $9(14.1 \%)$ & $55(85.9 \%)$ & & & \\
\hline Overall & $26(21.7 \%)$ & $94(78.3 \%)$ & & & \\
\hline \multicolumn{3}{|c|}{ Do you often finish your homework? $(n=120)$} & \multirow{4}{*}{0.006} & \multirow{4}{*}{1} & \multirow{4}{*}{0.937} \\
\hline Yes & $20(21.5 \%)$ & $73(78.5 \%)$ & & & \\
\hline No & $6(22.2 \%)$ & $21(77.8 \%)$ & & & \\
\hline Overall & $26(21.7 \%)$ & $94(78.3 \%)$ & & & \\
\hline
\end{tabular}

The proportion of students whose academic performance was good was higher for those who cared about doing well in school though this difference was not statistically significant as shown in Table 4.7. In addition, whether a student often got satisfied with his/her academic performance, or not, was not significantly related with academic performance. Students who viewed school rules as strict tended to perform poorly as opposed to those who were of the opinion that school rules were either moderate or not strict (Table 4.7). The academic performance of students, who often discussed their academic 
performance with someone, was not statistically different from their colleagues who had no one to discuss their performance with. Academic performance of students from two parent families was strongly associated with the individuals with whom he/she discussed the performance with $\left(\chi^{2}=11.177\right.$, df $=3, p=0.011$ ). Students who discussed with their fathers as well as those who discussed with relatives and others (teachers, friends, classmates, etc.) performed better as compared to those who discussed with mothers or both parents. Limiting the amount of time a student spent in pass time activities e.g. watching TV was not related statistically with academic performance as Table 4.7 shows. 
Table 4.7 Academic Performance of Students from Two Parent Families

\section{Two Parent Families}

Student Performance

\begin{tabular}{llllll} 
Characteristics & Good & Poor & $\chi^{2}$ & df & P-value \\
\hline $\begin{array}{l}\text { Parent contact school about student performance/ } \\
\text { behavior?(n=120) }\end{array}$ & & & \\
Yes & $26(23.6 \%)$ & $84(76.4 \%)$ & 3.017 & 1 & 0.082 \\
No & $0(0.0 \%)$ & $10(100.0 \%)$ & & & \\
Overall & $26(21.7 \%)$ & $94(78.3 \%)$ & & & \\
Do you often get satisfied with your performance? & $\mathbf{n = 1 2 2}$ & \\
Yes & $7(21.2 \%)$ & $26(78.8 \%)$ & 0.000 & 1 & 0.987 \\
No & $19(21.3 \%)$ & $70(78.7 \%)$ & & & \\
Overall & $26(21.3 \%)$ & $96(78.3 \%)$ & &
\end{tabular}

How do you view your school rules? $(\mathbf{n}=120)$

$\begin{array}{llllll}\text { Strict } & 5(12.8 \%) & 34(87.2 \%) & 2.664 & 1 & 0.103\end{array}$

Moderate/Not 21(25.9\%) 60(74.1\%)

strict

Overall 26(21.7\%) $\quad 94(78.3 \%)$

Do you discuss your performance with anybody? $n=122$ )

$\begin{array}{llllll}\text { Yes } & 23(21.9 \%) & 82(78.1 \%) & 0.158 & 1 & 0.691\end{array}$

No $\quad 3(17.6 \%) \quad 14(82.4 \%)$

Overall 26(21.3\%) $\quad 96(78.7 \%)$

Whom do you discuss your performance with? $(\mathbf{n}=105)$

$\begin{array}{llllll}\text { Father } & 14(32.6 \%) & 29(67.4 \%) & 11.177 & 3 & 0.011\end{array}$

Mother 2(5.3\%) $\quad 36(94.7 \%)$

Both parents $\quad 2(18.2 \%) \quad 9(81.8 \%)$

Relatives/others $\quad 5(40.0 \%) \quad 8(60.0 \%)$

Overall 23(38.5\%) $82(61.5 \%)$

Do your parent(s)/guardian(s) limit the amount of time you spend on pass time activities e.g. watching TV? $\mathbf{n}=\mathbf{1 1 8}$

\begin{tabular}{lrrrrr} 
Yes & $8(21.6 \%)$ & $29(78.4 \%)$ & 0.005 & 1 & 0.0942 \\
No & $18(22.2 \%)$ & $63(77.8 \%)$ & & & \\
Overall & $26(22.0 \%)$ & $92(78.0 \%)$ & & & \\
\hline
\end{tabular}


In two parent families, students whose parents often contacted the school to enquire about their academic performance and/ or behaviour performed equally well as those whose parents never or rarely did so $\left(\chi^{2}=0.100, d f=1, p=0.752\right)$. Attending school meetings or even taking part in the school activities by the parent was not found to contribute in a significant way to the student's academic performance (Table 4.8). Provision of the student with parental love/warmth did not show any association with student's performance in both types of families. This was also the case for the student getting advice about general life issues. Generally, students who reported that they often got assigned domestic duties at home performed poorly than those who reported the opposite. 
Table 4.8: Two Parent Families and Academic Performance of their Childreent Performance

\begin{tabular}{|c|c|c|c|c|c|}
\hline \multirow[b]{2}{*}{ Characteristic } & \multicolumn{2}{|c|}{$\begin{array}{l}\text { Two Parent Family } \\
\text { Student Performance }\end{array}$} & \multirow[b]{2}{*}{$\gamma^{2}$} & \multirow[b]{2}{*}{ df } & \multirow[b]{2}{*}{ P-value } \\
\hline & Good & Poor & & & \\
\hline \multicolumn{6}{|c|}{ Parent contact school about student performance/behaviour?(n=121) } \\
\hline Yes & $5(19.2 \%)$ & $21(80.8 \%)$ & 0.100 & 1 & 0.752 \\
\hline No & $21(22.1 \%)$ & $74(77.9 \%)$ & & & \\
\hline Overall & $26(21.5 \%)$ & $95(78.5 \%)$ & & & \\
\hline \multicolumn{6}{|c|}{ Attend school meetings/take part in the school activities? $(n=123)$} \\
\hline Yes & $17(24.3 \%)$ & $53(75.7 \%)$ & 2.327 & 1 & 0.127 \\
\hline No & $9(17.0 \%)$ & $44(83.0 \%)$ & & & \\
\hline Overall & $26(21.1 \%)$ & $97(78.9 \%)$ & & & \\
\hline \multicolumn{6}{|c|}{ Provides student with the love/warmth (s)he requires?(n=123) } \\
\hline Yes & $21(24.1 \%)$ & $66(75.9 \%)$ & 1.605 & 1 & 0.205 \\
\hline No & $5(13.9 \%)$ & $31(86.1 \%)$ & & & \\
\hline Overall & $26(21.1 \%)$ & $97(78.9 \%)$ & & & \\
\hline \multicolumn{6}{|c|}{ Student gets advise from parent about general life issues? $(n=123)$} \\
\hline Yes & $19(23.8 \%)$ & $61(76.3 \%)$ & 0.936 & 1 & 0.333 \\
\hline No & $7(16.3 \%)$ & $36(83.7 \%)$ & & & \\
\hline Overall & $26(21.1 \%)$ & $97(78.9 \%)$ & & & \\
\hline \multicolumn{6}{|c|}{ Student gets assigned domestic duties?(n=122) } \\
\hline Yes & $12(17.9 \%)$ & $55(82.1 \%)$ & 1.025 & 1 & 0.311 \\
\hline No & $14(25.5 \%)$ & $41(74.5 \%)$ & & & \\
\hline Overall & $26(21.3 \%)$ & $96(78.7 \%)$ & & & \\
\hline
\end{tabular}

The results presented in Table 4.9 show there was no relationship between parental marital status and academic performance. There was statistically no significant difference between the performance of students who hailed from single parent families and those from two parent families $\left(\chi^{2}=0.081\right.$, $\mathrm{df}=1, \mathrm{p}=0.776)$. The marital status of the parents were not associated significantly with the academic performance of the students $\left(\chi^{2}=0.702, \mathrm{df}=3, \mathrm{p}=0.873\right)$ as shown in Table 4.9. 
Table 4.9: Relationship between Parental Marital Status and students' Academic Performance

\section{Good}

\begin{tabular}{llllll} 
Characteristic & $(\mathrm{n}-37)$ & Poor $(n=143)$ & $\chi^{2}$ & df & P-value \\
\hline
\end{tabular}

Family student

hails from

Two parent

family

Single parent $\quad 11(19.3 \%) \quad 46(80.7 \%)$

family

Marital status

of parents

Married

$$
\text { 23(20.2\%) } 91(79.8 \%)
$$

$0.702 \quad 3$

0.873

Divorced

$6(18.2 \%) \quad 27(81.8 \%)$

Never married $\quad 5(27.8 \%) \quad 13(72.2 \%)$

Widowed

$3(20.0 \%) \quad 12(80.0 \%)$

\section{Differences in Academic Performance of Students from} Single and Two Parent Families

Based on the third study objective, "To establish if there is a difference in the academic performance of students from single and two parent families" results suggest that there is no significant difference in the academic performance of students from the two family structures $(\mathrm{p}=0.835)$ as shown in table 4.10, though the mean performance of students from two parent families is slightly higher. 
Table 4.10: Differences in Academic Performance of Students from Single and Two Parent Families.

\begin{tabular}{lcccccc}
\hline Family & Frequency & Mean & S.D. & df & t & P-value \\
\hline $\begin{array}{l}\text { Single parent } \\
\text { family }\end{array}$ & 57 & 5.4 & 2.50 & 178 & 0.2076 & 0.8358 \\
$\begin{array}{l}\text { Two parent } \\
\text { family }\end{array}$ & 123 & 5.5 & 2.49 & & & \\
\hline
\end{tabular}

\subsection{Gender Differences in Academic Performance}

Based on the fourth study objective, "To establish whether there are gender differences in academic performance of students from single and two parent families" analysis of variance in academic performance between male and female respondents revealed that male students had a higher mean than female students as shown in table 4.11.

Table 4.11: Gender Differences in Academic Performance

\begin{tabular}{lccl}
\hline Gender & Mean & Frequency & $\begin{array}{l}\text { Standard } \\
\text { Deviation }\end{array}$ \\
\hline Male & 5.63 & 89 & 2.529 \\
Female & 5.32 & 97 & 2.502 \\
Total & $\mathbf{5 . 4 7}$ & $\mathbf{1 8 6}$ & $\mathbf{2 . 5 1 3}$ \\
\hline
\end{tabular}

There was no statistically significant difference between the two groups ( $\mathrm{p}=0.403)$ as shown in Table 4.12. 
Table 4.12: Analysis of Variance in Academic Performance by Gender

\begin{tabular}{llllll}
\hline & $\begin{array}{l}\text { Sum of } \\
\text { squares }\end{array}$ & df & $\begin{array}{l}\text { Mean } \\
\text { squares }\end{array}$ & F & P \\
\hline $\begin{array}{l}\text { Between groups } \\
\text { (Combined) }\end{array}$ & 4.450 & 1 & 4.450 & 0.703 & 0.403 \\
Within groups & 1163.857 & 184 & 6.325 & & \\
Total & 1168.306 & 185 & & & \\
\hline
\end{tabular}

Male students from single parent families had a higher mean than males from two parent families while female students from two parent families had a higher mean than those from single parent families (Table 4.13).

Analysis of variance showed no statistically significant difference between gender and type of family $(\mathrm{p}=0.348)$ as shown in table 4.14. 
Table 4.13: Differences in Academic Performance with Student's Gender and Type of Family

\begin{tabular}{llrrr} 
Gender & $\begin{array}{l}\text { Type of family one } \\
\text { hails from }\end{array}$ & Mean & Frequency & $\begin{array}{c}\text { Std. } \\
\text { Deviation }\end{array}$ \\
\hline Male & Two parent family & 5.6 & 62 & 2.583 \\
& Single parent family & 5.8 & 25 & 2.517 \\
& Total & 5.66 & 87 & 2.551 \\
Female & Two parent family & 5.41 & 61 & 2.493 \\
& Single parent family & 5.09 & 32 & 2.532 \\
& Total & 5.3 & 93 & 2.497 \\
Total & Two parent family & 5.5 & 123 & 2.53 \\
& Single parent family & 5.4 & 57 & 2.527 \\
& Total & 5.47 & 180 & 2.522 \\
\hline
\end{tabular}

Table 4.14: ANOVA: [Variation of performance with

\begin{tabular}{llllll}
\multicolumn{5}{c}{ student's gender and type of family] } \\
\hline & $\begin{array}{l}\text { Sum } \\
\text { squares }\end{array}$ & Df & $\begin{array}{l}\text { Mean } \\
\text { square }\end{array}$ & F & p-value \\
\hline $\begin{array}{l}\text { Between groups } \\
\text { (combined) }\end{array}$ & 5.636 & 1 & 5.636 & 0.885 & 0.348 \\
W i t h i n & 1133.225 & 178 & 6.366 & & \\
groups & & & & & \\
Total & $\mathbf{1 1 3 8 . 8 6 1}$ & $\mathbf{1 7 9}$ & & & \\
& & & & & \\
\hline
\end{tabular}




\section{Discussion}

Based on university's admission criteria in Kenya, most students from both family structures can be said to be unqualified for university admission; majority (79.6\%) of the students got an average grade of $\mathbf{C}$ and below which was rated as below minimum entry requirement for university and only $20.4 \%$ attained an average grade of $\mathbf{C}+$ and above which was rated as satisfactory for entry to university. These findings support a previous study carried out by Misoy (2011) in Nandi District which found that majority of secondary day students perform below the university entry grade $\mathbf{C}+$.

The study found there was no relationship between single parent families and the academic performance of their children. Students from divorced, never married and widowed parents were grouped as from single parent families though students from divorced families were found to perform poorly than the rest. This agrees with the finding of CMF (2005) that found divorce to have negative effects on children which have a bearing on performance. Students from families whose parents never got married were found to perform better than the rest. There was also no relationship between two parent families and the academic performance of their children. Most parents from both families showed lack of involvement in their children's academic and extracurricular activities and did not control the amount of time their children spent in 
pass time activities or with friends. They also did not contact school about their children's performance. These were found to be contributory factors of the poor performance in both cases, agreeing with the finding of Crowe (2003). Although there was no significant relationship between assignment of duties and academic performance of students in the two types of families, majority of students reported that they often got assigned domestic duties at home and performed poorly than those who were not assigned. This confirms the results of Omenge and Nasongo (2010) that student's low achievement could be attributed to involvement in domestic chores.

Students from the two types of families who cared about doing well in school had a higher performance than those who did not. This agrees with the finding of Brown (2002) which found that students who cared about doing well in school obtained a higher performance index. Those who viewed school rules as strict tended to perform poorly as opposed to the ones who opined that rules were either moderate or not strict agreeing with the finding of Crowe (2005). From these findings, parental marital status does not determine the performance of the student. Therefore the study fails to reject hypotheses 1 and 2 which are stated as follows respectively: there is no significant relationship between single parent families and academic performance of their children in day secondary schools; and there is no significant relationship between two parent families and the academic performance 
of their children in day secondary schools.

There was no statistically significant difference between the academic performance of students from single and two parent families. The students from two parent families had a slightly higher mean than those from single parent families, though this difference was not statistically significant. These findings are consistent with similar findings of the research carried out in Nigeria by Edun and Oguntola (2011) who found that there was no significant difference in the academic achievement of pupils from families with two parents, single parents or no parents. It also supports the findings of Heyneman and Lomey (1983) that the portion of the variance in achievement related to family background was much smaller than that attributed to school quality in developing countries compared to developed countries. These findings also agree with that of Ushie, Emeka and Owolabi (2012) which found that family structure did not determine student's academic performance in Nigeria. Therefore the study fails to reject hypothesis 3 which states that there is no difference in academic performance of students from single and two parent families in day secondary schools.

The general mean performance of the boys was higher than that of the girls though there was no significant difference between the academic performances of the two groups. Also comparing the males and females from single parent families showed no significant difference with their counterparts from 
the two parent families. The male students from two parent families had lower mean point as compared to those from single parent families where as the female students from two parent families had a higher mean compared to those from single parent families though in both cases there was no significant difference. Therefore the study fails to reject the fourth hypothesis that there are no significant gender differences in academic performance of students from single and two parent families.

Based on the findings of the study, the academic performance of students from both two and single parent families can be said to be generally the same and therefore parental marital status did not determine the students' academic performance. The study found that poor performance can be associated with factors outside the family structure like not doing studies at home and being assigned home chores. Doing studies at home was significantly associated with improved academic performance, connectedly, those who studied at home performed better than those who didn't. The study found that majority of students from both families did not do their studies at home which could be a contributory factor of the general poor performance. Other contributing factors to academic performance included missing school, non participation in class, not caring about doing well and negative view of students on school rules and regulations. The age of the students was also found to affect the academic performance with those 
aged 16 years or less performing better than the older students though there was no significant association between age and academic performance.

The students also stated additional factors which affected their performance; on top is poverty which made the parents from both the single and two parent families not provide the necessary school materials for their children. These findings were similar with the findings of Agba et al (2009), that even when a child lives with both parents, extreme poverty can affect the student's performance due to lack of school material. It also agrees with the finding of Eamon (2005) and Jeynes (2002) that low social-economic status has significant negative effects on the academic achievement of students because it is an obstruction to vital resources and creates additional stress at home. Some students from two parent families also stated that conflicts and misunderstanding between their parents affected their academic performance hence presence of two parent families does not necessarily lead to high performance. These confirmed the findings of the studies carried out by CMF (2005) and Boute (2001) who found that the level of family cohesion and family relationships predict students' performance. These findings agree with that of Ushie et al (2012) that although parental marital status is not significantly related to academic performance of students other family characteristics are a major source of student's educational performance. 
The family system theory states that individuals are best understood within the context of relationships within the family and if there are dysfunctions it may lead to inability of the members to operate productively (Goldenberg and Goldenberg, 2008). In the study some students indicated unhealthy relationships within the family which lead to psychological problems lowering their academic performance. A combination of other factors which were not catered for in this study like school factors, personal factors relating to the individual's intelligence and social factors may also have affected the student's performance as found out by a research carried out by Crowe (2005) and Suleman et al, (2012). Therefore, there is a combination of various factors that affect a student's academic performance. The findings of the study may make an important contribution to the knowledge pool concerned with the relationships between family structures and academic performance.

\section{Conclusion}

The results of this study indicate that parental marital status does not determine the academic performance of students in day secondary schools of Dagoretti Sub District of Nairobi County. However, home environment was observed to be playing an important role in students' academic performance. This was because irrespective of parental marital status, other family characteristics like assignment of domestic duties, 
poverty, parent's participation and home environment were found to affect academic performance. It is therefore important to provide healthy home/family and school environments to enhance academic performance in both single and two parent families.

The study recommends the following: Parental participation in children's education to be encouraged and caregivers to consider assigning learners minimal domestic chores so as to have enough time for studies. Additionally, enriching home/ family environments should be provided for effective learning to happen and finally, counselors to step in and provide much needed psychosocial support to the growing and developing teenagers/young adults. More research is needed on the contribution of the home/family environment on academic performance. 


\section{References}

Agba M.S., Agba A.O., Ushier, E.M. \& Akwara, A.F. (2009). Poverty, food and insecurity and rebranding question in Nigeria. Canadian social sciences 5(6)1-9

Ajila, C., \& Olutola, A. (2007). Impact of parents' socio-economic status on university students' Academic performance. Ife Journal of Educational Studies, 7(1), 31:39.

Amato, P. R. (2001). Children of divorce in the 1990s: An update of the Amato and Keith (1991) MetaAnalysis. Journal of family psychology, 15, 355-70.

Bagaka, J. G. (2010) Many Districts left behind: An individual change analysis of inequity in the Kenyan primary education opportunities. International Journal of Educational Development, 30 (6), 586-591.

Brown, S. L. (2004). Family Structure and Child WeilBeing: The Significance of Parental Cohabitation. Journal of Marriage and the Family 66 (2), 362.

Buote, C. A. (2001). Relations of autonomy and relatedness to school functioning and psychological adjustment during adolescence. Dissertation Abstracts international section A: Humanities and social sciences, $62(1)$. 
Center for Marriage and Families (2005). Family Structure and Children's Educational Outcomes. Research Brief No.1. Institute for American Values, New York, NY 10023.

Conley, D., \& Glauber, R. (2005). Parental educational investment and children's risk: Estimates of the impact of sibling size and birth order from exogenous variation in fertility. NBER Working papers no. 11302.

Crowe, R.E. (2005). Does it start at home? An analysis of the effects of family structure on academic achievement. A master's thesis submitted to Columbia College of Wichita State University.

Downey, D. B. (1995). When bigger is not better: family size, parental resources and children's educational performance. American sociological review 60:746-761.

Eamon, M.K (2005). Social-demographic, school, neighborhood and parenting influences on academic achievement of Latino young adolescents. Journal of Youth and Adolescence, 34(2), 163-175.

Edun, T., \& Ogontula, S. (2011). The impact of Parenthood and Birth order on Academic Achievement of pupils in Abeokuta south local government area, Ogun state, Nigeria European Journal of social sciences 20 (4). 
Fagan, F. P., Have, L. T., and Chen, W. (2011). Marriage, Family Structure, and children's Educational Attainment. Marriage and religion research institute: Washngton. D. C.

Goldenberg, I., \& Goldenberg, H. (2008). Family therapy: An overview. Belmont, CA: Thomson Brooks/Cole. Heyneman S.P. \& Lomey, W.A. (1983). The effects of primary school quality on academic achievement across twenty-nine high and low income countries. American journal of sociology 88:116-294.

Jagero, N. O. (2011). An Evaluation of School Environmental Factors Affecting Performance of Boarding Secondary Students in Kenya. African Journal of Education and Technology, 1(1), 127-138.

Jeynes, W.H. (2002). Examining the effect of parental absence on the academic achievement of adolescents: The challenge of controlling for family income. Journal of family and economic issues 23(2)

Lewin, K. M. (2004). Anticipation and Planning Association for Development of Education in Africa. Washington D.C: World Bank.

Misoy, E.C. (2001). Factors affecting academic achievement of day secondary schools in Nandi District. African journal of education and technology 2(4), $156-164$.

Omenge, B. N. (2010). Effects of socialization with regard to gender roles on students' academic achievement in 
secondary schools in Kenya. Current Research Journal of social sciences 2 (6): 327-333.

Orr, A. J. (2003). Black-White differences in achievement: the importance of wealth. Sociology of education 76: 281-304.

Ploeg, M. V. (2000). Children from disrupted families as adult: Family Structure, college attendance and college completion. Economic of education review 21:171-84.

Suleman, Q. Aslam, D.H., Sarwar, S., Lodhi, A. M., \& Hussain, I. (2012). Factors responsible for unsatisfactory academic of secondary school students in rural areas of Kohat Division, Pukhtunkhwa (Pakistan). American Journal of scientific research 43: 46-57.

Uwaifo, V. O. (2008). The Effects of Family Structure and Parenthood on the Academic Performance of Nigerian University Students. Stud Home Comm Sci, 2(2): 121-124.

Usie, M.A., Emeka, J.O., Ononjga, G.I., \& Owolabi, E. (2012). Influence of family structure on students academic performance in Agege local government area, Lagos State, Nigeria. European Journal of educational studies 4(2)

World Bank, (2002). Making Services Work for poor people: World Development Report. Washington D.C: World Bank. 